\title{
Elżbieta Dolata
}

Uniwersytet Rzeszowski

\section{Czasopisma galicyjskie wobec problemów higieny szkolnej}

Na przełomie XIX i XX w. w Galicji, podobnie jak w całej Europie, nastąpiło ożywienie zainteresowania sprawami higieny szkolnej. Wynikało ono z rozwijającego się intensywnie ruchu higienicznego, którego podłożem były odkrycia naukowe i rozwój nauk przyrodniczych. Jego przedstawiciele przekonywali, że podstawą osiagnięć dydaktycznych i wychowawczych szkoły jest zdrowie dzieci i młodzieży, podkreślali konieczność upowszechniania wiedzy higienicznej i przystosowania warunków nauki szkolnej do potrzeb rozwojowych uczniów. W popularyzację wiadomości z zakresu zdrowia i higieny oraz walkę o poprawę stanu sanitarno-higienicznego szkół żywo włączyła się galicyjska prasa. Liczne artykuły poruszające problemy higieny szkolnej zamieszczane były zarówno w periodykach pedagogicznych, czasopismach będących organami towarzystw lekarskich i higienicznych oraz prasie codziennej.

Analiza artykułów zamieszczanych w prasie galicyjskiej pozwoliła wyodrębnić kilka zagadnień, wokół których koncentrowali się autorzy publikowanych tekstów. Wśród nich należy wymienić:

- informacje o warunkach sanitarno-higienicznych szkół galicyjskich,

- dane o stanie zdrowia uczniów i chorobach szkolnych,

- apele, petycje do władz szkolnych o poprawę warunków nauki,

- zarządzenia władz krajowych i szkolnych dostosowujące organizację procesu nauczania do norm higienicznych,

- sprawozdania z kongresów, zjazdów i wystaw higienicznych,

- recenzje nowości wydawniczych o tematyce higienicznej,

- pogadanki higieniczne dla dzieci, rodziców i nauczycieli.

Charakterystyce warunków sanitarno-higienicznych w szkołach galicyjskich, najwięcej miejsca poświęcała prasa pedagogiczna. Liczne teksty poruszające tę tematykę zamieszczało na swych łamach, m.in. pierwsze czasopismo pedagogiczne „Szkoła”, ukazujące się we Lwowie w latach 1868-1939 jako organ Towarzystwa Pedagogicznego ${ }^{1}$. W jednym z artykułów zamieszczonych na łamach „Szkoły”

${ }^{1}$ A. Stopińska-Pająk, Wkład czasopisma ,Szkoła” w rozwój myśli pedagogicznej, [w:] Galicja i jej dziedzictwo, t. 8. Myśl edukacyjna w Galicji 1772-1939, red. Cz. Majorek, A. Meissner, Rzeszów 1996, s. 170. 
w 1886 r. czytamy: „Piecza nad fizycznym wychowaniem młodzieży to najsłabsza strona dzisiejszego ustroju szkół. Dziecko od 6 lat zaprzęgnięte do pracy umysłowej, tkwi kilkanaście lat nad książką w domu i szkole, pozbawione koniecznego w tym czasie ruchu i powietrza. Szkoła zbyt mało uwagi przywiązuje do higienicznej strony wychowania. Umieszczenie wielu szkół uraga najprymitywniejszym zasadom higieny, izby rzadko zamiatane, bez wentylacji, przepełnione dziatwa, bez ogrodu, bez zdrowej wody do picia, dzieci chore ze zdrowymi. Smutne następstwa tego zaniedbania to zbiorowisko nieszczęśliwych istot bez krwi i kości, noszące w sobie zadatek cherlactwa, jeśli nie przedwczesnej śmierci. Upadek fizyczny odbija się nie tylko na wynikach nauki. Konieczne jest popularyzowanie wiadomości z higieny, nakierowanie słowem i przykładem do ich przestrzegania, rozbudzenie zamiłowania do gimnastyki, przebywania na świeżym powietrzu, kształtowanie siły, przezorność i przytomność umysłu, higieniczne urządzanie budynków szkolnych, zapobieganie szerzeniu chorób"2. Słowa te dosadnie obrazują bardzo zły stan sanitarno-higieniczny szkół galicyjskich. Jego niekorzystny wpływ na zdrowie uczniów podkreślało wielu autorów publikowanych na łamach „Szkoły” tekstów. Przykładowo M. Baranowski w artykule $O$ tawkach szkolnych $i$ ich wptywie na zdrowie młodzieży pisał: „ławki mają w przeważającej ilości szkół wymiary, odpowiadające wzrostowi ludzi dorosłych [...] pulpity ławek oddalone bardzo od siedzeń, często nie mają żadnego nachylenia, albo nawet mają nachylenie wadliwe w kierunku przeciwnym normalnemu. Siedzenie w takich ławkach przez kilka godzin dziennie powoduje wady postawy"’3. W innym artykule M. Baranowski poruszał problem nadmiernego przepełnienia klas, przyczyniającego się do rozprzestrzeniania chorób wśród uczniów ${ }^{4}$. Podobne spostrzeżenia zawierają artykuły J. Chmielewskiego O nauce pod względem wptywu na zdrowie dzieci i F. Obtułowicza Kilka uwag $w$ sprawie higieny budynków szkolnych oraz z zakresu higieny szkolnej ${ }^{5}$. O nadmiernym obciążeniu dzieci nauką oraz nieracjonalnym rozkładzie zajęć i przerw międzylekcyjnych pisali natomiast J. Nowicki, A. Reifel. W swoich artykułach prezentowali, jako godny do naśladowania przykład, szkoły angielskie oraz francuskie wybudowane, wyposażone i funkcjonujące $\mathrm{z}$ uwzględnieniem wszelkich norm higienicznych ${ }^{6}$.

${ }^{2}$ R. Starkel, Stosunki zdrowotne w szkole, „Szkoła” 1886, nr 20, s. 153.

${ }^{3} \mathrm{M}$. Baranowski, O ławkach szkolnych i ich wplywie na zdrowie młodzieży, „Szkoła” 1888, nr 22, s. 186.

${ }^{4}$ M. Baranowski, Jakie nastęstwa dla zdrowia, nauki i wychowania młodzieży sprowadza przepetnienie klas $w$ szkole, „Szkoła” 1885, nr 28, s. 231.

${ }^{5}$ J. Chmielewski, O nauce pod względem wpływu na zdrowie dzieci, „Szkoła” 1878, nr 6, s. 41; F. Obtułowicz, Kilka uwag $w$ sprawie higieny budynków szkolnych oraz z zakresu higieny szkolnej, ,Szkoła” 1897, nr 34, s. 385.

${ }^{6} \mathrm{~J}$. Nowicki, O szkodliwych wptywach na jakie narażona jest młodzież szkót naszych pod względem fizycznym i co czynić należy, by złemu zaradzić, „Szkoła” 1900, nr 12, s. 92, nr 13, s. 98; A. Reifer, Przyczynek do higieny szkolnej, „Szkoła” 1880, nr 1, s. 56. 
Zagadnienia dotyczące sytuacji sanitarno-higienicznej szkół galicyjskich gościły również dość często na łamach „Rodziny i Szkoły”. Czasopismo to ukazywało się we Lwowie w latach 1896-1913, jego pierwszymi redaktorami byli: Mieczysław Baranowski i Franciszek Majchrowicz ${ }^{7}$. Na szczególną uwagę zasługuje artykuł B. Baranowskiego Szkolnictwo ludowe Galicji w swym rozwoju od 1868 do 1909, z uwzględnieniem stosunków higienicznych, w którym autor zaprezentował stan sanitarno-zdrowotny szkół na przestrzeni 40 lat $^{8}$. Artykuł ten potwierdza niekorzystne warunki panujące w szkołach ludowych przez kilkadziesiąt lat. Jeszcze pod koniec XIX w. większość budynków było drewnianych, w bardzo złym stanie technicznym i higienicznym. Z drewna wykonywano zwykle ściany, schody i podłogi. Ze względu na cenę używano drewna gorszej jakości, miękkiego, co powodowało, że w podłogach pojawiały się szpary, a w nich gromadził się brud. Podłogi zapuszczano olejem, który miał wiązać pył i kurz, myto je przeważnie tylko dwa razy w roku. By zaoszczędzić na ogrzewaniu, budowano wąskie korytarze, małe i niskie sale lekcyjne, których wysokość nie przekraczała $2,5 \mathrm{~m}$. W budynkach znajdowało się niewiele okien, toteż ,w miesiącach zimowych panował w izbach szkolnych oświetlonych $\mathrm{w}$ ten sposób, przez znaczną część dnia szary mrok [...] często bywały one pozabijane gwoździami stale, tak że o jakiejkolwiek wentylacji nie było mowy"’. Na stan sanitarno-higieniczny szkół uskarżali się również autorzy innych artykułów zamieszczanych na łamach „Rodziny i Szkoły”, m.in. G. Kubik-Horodyński i J. Dobrzański ${ }^{10}$. W czasopiśmie znajdujemy ponadto liczne teksty odnoszące się do kwestii zdrowia uczniów. Na uwagę zasługuje tu artykuł B. Kaczorowskiego Stan higieny i stan zdrowotny dzieci szkót średnich we Lwowie. Zawiera on wyniki badań lekarskich, którym w roku szkolnym 1910/11 poddano 3051 dzieci rozpoczynających naukę $\mathrm{w}$ szkołach średnich. Zamieszczone dane obrazują stan higieny i zdrowia dzieci szkolnych we Lwowie. Z informacji zawartych w artykule wynika, że u 263 (8,65\%) dzieci stwierdzono zmiany w kręgosłupie, na nieżyt oskrzeli i płuc chorowało 156 (5,15\%) dzieci, 2708 $(88,7 \%)$ było brudnych, 1741 (57\%) słabo odżywionych, 2908 (95,3\%) miało zepsute zęby ${ }^{11}$. Okazuje się więc, że powszechny był brak dbałości o higienę

\footnotetext{
${ }^{7}$ A. Meissner, Polskie czaspisma pedagogiczne w Galicji, [w:] Galicja i jej dziedzictwo, t. 8. Myśl edukacyjna w Galicji 1772-1918, s. 136.

${ }^{8}$ B. Baranowski, Szkolnictwo ludowe Galicji w swym rozwoju od 1868 do 1909, z uwzględnieniem stosunków higienicznych, „Rodzina i Szkoła” 1910, nr 17-18, s. 301.

${ }^{9}$ Tamże.

${ }^{10}$ G. Kubik-Horodyński, Wychowanie i nauka ze stanowiska polityki socjalnej, „Rodzina i Szkoła” 1897, nr 11, s. 549; J. Dobrzański, Wychowanie fizyczne i higiena szkót, „Rodzina i Szkoła" 1908, nr 1/2, s. 3.

${ }^{11}$ B. Kaczorowski, Stan higieny i stan zdrowotny dzieci szkót średnich we Lwowie, „Rodzina i Szkoła" 1911, nr 4, s. 282.
} 
ciała, jamy ustnej i sposób odżywiania, co sprzyjało powstawaniu i rozprzestrzenianiu się chorób wśród uczniów.

Wiele tekstów o stanie zdrowia uczniów i niekorzystnych warunkach nauki w szkołach jako przyczynach chorób znajdujemy na łamach popularnego w Galicji czasopisma „Muzeum”. Ukazywało się ono we Lwowie, w latach 1885-1939 jako organ Towarzystwa Nauczycieli Szkół Wyższych, adresowane było do osób związanych ze szkolnictwem średnim ${ }^{12}$. W ramach treści higieniczno-lekarskich „Muzeum” prowadziło ostrą walkę z przeciążeniem szkolnym, przepełnieniem szkół, fatalnym ich wyposażeniem oraz starało się o należyte miejsce dla wychowania fizycznego w programach szkolnych. Dowodem na to jest duża ilość artykułów o tej tematyce ${ }^{13}$.

W roku 1912 na łamach „Muzeum” zamieszczono interesujący artykuł, zawierający szczegółowe zestawienie stanu sanitarnego budynków wszystkich galicyjskich gimnazjów, szkół realnych i seminariów nauczycielskich w roku szkolnym 1911/12. Wynika z niego, że baza lokalowa tych szkół była bardzo skromna. Wiele $\mathrm{z}$ nich znajdowało się $\mathrm{w}$ budynkach nienadających się do celów szkolnych, powszechnie brakowało odpowiedniego wyposażenia $\mathrm{w}$ pomoce i sprzęty szkolne, a także toalet i sal gimnastycznych ${ }^{14}$.

Sprawy dotyczące zdrowia i higieny w szkołach galicyjskich poruszane były często podczas dyskusji i walnych zebrań TNSW, z których sprawozdania publikowano również na łamach „Muzeum”. Przykładowo w sprawozdaniu z roku 1901 czytamy: „W jednym z większych gimnazjów tutejszych zwanych Bernardyńskim w sali VA [...] przebywa około 40 chłopców, w dnie świąteczne wszakże odbywają się tu nabożeństwa szkolne i zbiera się wtedy około 400 chłopców [...] sala długa, wąska, ściana okienna oszalowana drzewem dla przysłonięcia wilgoci, na tej ścianie 40 płaszczów, na ucznia około 2 metry sześcienne powietrza przesyconego wilgocią ze ściany, wyziewami z wietrzących się płaszczów, oraz ze stajni sąsiednich koszar. Podłoga w salach z desek miękkich, między deskami szpary gdzie składa się pył znoszony tu przez

${ }^{12}$ T. Gumuła, Z dziejów „Muzeum” 1885-1939. W setna rocznicę założenia czasopisma, [w:] Z historii szkolnictwa i myśli pedagogicznej w Polsce (1779-1939), red. S. Walasek, Wrocław 1990, s. 169-179; F. Majchrowicz, Czterdziestoletni jubileusz czasopisma „Muzeum” 1885-1925, Księga pamiątkowa, Lwów 1925.

${ }^{13}$ A. Sokołowski, O stosunkach higienicznych $w$ naszych szkołach średnich, „Muzeum” 1888, R. IV, s. 384-395, s. 587; A. Pechnik, Kilka uwag z zakresu higieny szkolnej (o kurzu w izbach szkolnych), „Muzeum” 1898, nr 8/9, s. 640; B. Mańkowski, Oświetlenie klas, „Muzeum” 1901, R. XVII, s. 73; Przepetnienie naszych szkót, „Muzeum” 1906, t. 2, s. 342; A. Bolland, Analiza powietrza w salach szkolnych c.k. Wyższej Szkoty Realnej w Tarnowie, „Muzeum” 1907, t. 1, s. 414; Gabka jako rozsadnik zarazków chorobotwórczych, „Muzeum” 1910, t. 1, s. 98; J. Landau, Szkoła a choroby zakaźne, „Muzeum” 1902, R. XVIII, s. 726, 846; Nauka szkolna a zdrowotność, „Muzeum” 1910, t. 1, s. 67.

${ }^{14}$ Pomieszczenie galicyjskich szkót średnich (gimnazjów, szkót realnych i seminariów nauczycielskich), „Muzeum” 1912, t. 2, s. 11-50. 
dziesiątki pokoleń uczniów i czeka tylko sposobności, aby stać się okazją do wzniecenia epidemii odry lub szkarlatyny i dostarczyć w ten sposób wiarygodnego dowodu o niezdrowotności budynków" ${ }^{\prime 1}$. W tym samym sprawozdaniu czytamy o stanie szkolnych toalet, mianowicie: „Klatka na poczekaniu z desek zbita, nieogrzana, przedzielona przepierzeniem na dwa przedziały wychodkowe, przy bocznej ścianie drewniana rynienka dla odprowadzania moczu, przy niej miejsce dla dwóch, trzech osób, podłoga drewniana zalana moczem i kałem. Podczas pauz tłok kilkudziesięciu chłopców załatwia swe czynności wydzielania. Nadto co godzinę kilkadziesiąt stóp ludzkich roznosi mocz i kał po salonach szkolnych, przesycając gnojówke; bakteriami gnilnemi sieknącą w swe pory i szpary miękką podłogę szkolną"16. Takie opisy potwierdzają fatalny stan sanitarno-higieniczny szkół galicyjskich.

Liczne artykuły z zakresu higieny szkolnej pojawiały się również na łamach prasy lekarskiej i higienicznej. Spośród czasopism lekarskich na szczególną uwagę zasługuje „Przegląd Lekarski”, założony w 1862 r. Początkowo był on organem Towarzystwa Naukowego Krakowskiego, a następnie od roku 1873 Towarzystwa Lekarskiego Krakowskiego i Towarzystwa Lekarzy Galicyjskich we Lwowie. Redaktorem naczelnym przez wiele lat był Leon Blumenstok. Kilka artykułów z zakresu higieny szkolnej zamieszczono również na łamach „Dwutygodnika Higieny Publicznej Krajowej”, który wydawano tylko przez rok od 1872 jako dodatek do „Przeglądu Lekarskiego”. Od 1876 r. ukazywał się „Dwutygodnik Higieniczny”, również jako dodatek do „Przeglądu Lekarskiego”. Był on organem sekcji higienicznej Towarzystwa Lekarskiego Krakowskiego. Istotny dla propagowania wiedzy higienicznej był ponadto „Przewodnik Higieniczny", wydawany od 1889 r. jako organ Towarzystwa Opieki Zdrowia w Krakowie. Redaktorem czasopisma był początkowo dr Bolesław Lutostański, a następnie przez wiele lat dr Henryk Jordan. W periodyku istniała stała część dotycząca prac Towarzystwa Opieki Zdrowia, poza tym publikowano artykuły $\mathrm{z}$ zakresu szeroko rozumianej higieny, w tym higieny szkolnej. Podobną tematykę poruszano na łamach „Przeglądu Higienicznego”- organu Towarzystwa Higienicznego, wydawanego w latach 1902-1913 we Lwowie ${ }^{17}$.

Prasa lekarska i higieniczna zamieszczała głównie artykuły o chorobach szkolnych, których przyczyną było przebywanie w nieodpowiednich warunkach sanitarno-higienicznych. W jednym z artykułów, zamieszczonych w „Przewodniku Higienicznym”, N. Cybulski dokonał charakterystyki najczęstszych chorób szkolnych. Zaliczył do nich: krótkowzroczność, występującą jako efekt nieodpowiedniego oświetlenia sal lekcyjnych, wady postawy spowodowane siedze-

${ }^{15}$ S. Badzyński, Sprawozdanie z siedemnastego Walnego Zgromadzenia TNSW odbytego we Lwowie w dniach 26 i 27 maja 1901 roku, ,Muzeum” 1901, R. XVII, s. 657.

${ }^{16}$ Tamże, s. 670.

${ }^{17}$ A. Meissner, Polskie czasopisma...; S. Możdżeń, J. Musiał, Bibliografia polskich czasopism pedagogicznych (do 1979), Kielce 1981. 
niem $\mathrm{w}$ źle skonstruowanych ławkach, zaburzenia $\mathrm{w}$ trawieniu powstające w wyniku nieprawidłowego odżywiania i stresu, choroby płuc wynikajace z przebywania w wilgotnych, zakurzonych, rzadko wietrzonych klasach ${ }^{18}$. Autorzy artykułów - lekarze na łamach czasopism higienicznych i lekarskich udzielali nauczycielom i rodzicom cennych wskazówek odnośnie do postępowania z dziećmi w przypadku wystapienia jakichkolwiek objawów chorobowych ${ }^{19}$.

Pod koniec XIX w. w wielu czasopismach publikowano apele i petycje do władz państwowych i szkolnych o podjęcie działań zmierzających do poprawy stanu higieny szkolnej. Postulaty poprawy warunków sanitarno-higienicznych w szkołach zamieszczały zarówno pisma pedagogiczne, higieniczne, jak i lekarskie. O randze problemu świadczy ilość artykułów, postulujących przeprowadzenie reformy higienicznej w szkołach galicyjskich ${ }^{20}$. Wielu autorów podawało konkretne propozycje reform higienicznych. Przykładowo w artykule zawartym na łamach „Przewodnika Higienicznego” pt. Jak ma być urzadzona szkoła i nauka szkolna, aby odpowiadała zasadom higieny szkolnej, J. Maciołowski przytoczył normy higieniczne, które powinny być przestrzegane podczas budowy nowych szkół, wyposażania ich w sprzęty szkolne i pomoce naukowe oraz zasady higieny nauczania ${ }^{21}$. Z kolei $\mathrm{w}$ artykule $O$ potrzebie zaprowadzenia obowiqzkowej nauki higieny $w$ szkołach średnich, zamieszczony jest apel o wprowadzenie obowiązkowej nauki higieny we wszystkich typach szkół ${ }^{22}$. Liczni autorzy podkreślali ponadto konieczność wprowadzenia w szkołach stałej opieki medycznej i zatrudnienie lekarzy szkolnych. Na ten temat pisali głównie lekarze: T. Żuliński, W. Serbeński, S. Bądzyński, L. Salo i inni ${ }^{23}$. Wszyscy byli

${ }^{18}$ N. Cybulski, O wplywie szkoły współczesnej na fizyczny rozwój młodzieży szkolnej, „Przewodnik Higieniczny" 1890, nr 6, s. 149.

${ }^{19}$ Radecki, Z hygieny szkolnej, „Przewodnik Higieniczny” 1884, nr 9, s. 257. A. Pietrzycki, Szkoła i jej wplyw przemożny na powstanie i szerzenie się nagminnego zapalenia gruczołu zausznego, „Przegląd Lekarski” 1892, nr 9, s. 110.

${ }^{20}$ L. Glück, Kilka uwag $w$ sprawie reformy higienicznej szkół naszych, „Przegląd Lekarski” 1881, nr 19, s. 258; B. Lutostański, W sprawie reformy szkolnej, „Przegląd Lekarski 1880, nr 19, s. 352; Memoriat w sprawie pożadanej reformy higienicznej szkół naszych, „Przegląd Lekarski” 1881, nr 15, s. 196; T. Żuliński, Kilka stów w sprawie higienicznej reformy szkót, „Przegląd Lekarski” 1881, nr 25, s. 354, nr 26, s. 370, nr 27, s. 383, nr 28, s. 395, nr 29, s. 408; T. Żuliński, O potrzebie stałego higienicznego nadzoru nad zakładami wychowawczo-naukowymi, „Przegląd Pedagogiczny” 1882, nr 1, s. 1, nr 2, s. 38, nr 3, s. 77, nr 4, s. 112, nr 5, s. 156, nr 6, s. 179, nr 7, s. 206.

${ }^{21}$ J. Maciołowski, Jak ma być urzqdzona szkoła i nauka szkolna, aby odpowiadała zasadom higieny szkolnej, „Przewodnik Higieniczny” 1892, nr 7, s. 201, nr 9, s. 266, nr 10, s. 297.

${ }_{22}$ F. Obtułowicz, O potrzebie zaprowadzenia obowiazkowej nauki higieny w szkołach średnich, ,Przegląd Higieniczny” 1905, nr 11, s. 254-255.

${ }_{23}^{23}$ T. Żuliński, O potrzebie stałego dozoru nad szkołami, „Przegląd Lekarski” 1882, R. XXI, s. 12; J. Merunowicz, O nadzorze lekarskim w szkołach, „Muzeum” 1888, R. IV, s. 33-39; A. Beck, W sprawie lekarzy szkolnych, „Przegląd Lekarski” 1890, nr 28, s. 406; A. Koral, Lekarz szkolny, „Przegląd Pedagogiczny” 1892, nr 16, s. 207, nr 17, s. 221; L. Salo, W sprawie lekarzy szkolnych, „Muzeum” 1890, nr 4, s. 259; W sprawie nadzoru lekarskiego w naszych szkołach 
zgodni co do tego, że zatrudnianie w szkołach lekarzy przyczyniłoby się do poprawy stanu zdrowia uczniów. Lekarze prowadziliby systematyczne badania dzieci, podejmowali odpowiednie działania zapobiegające epidemiom, upowszechniali wśród uczniów zasady higieny.

Liczne publikacje, udowadniające wpływ nieodpowiednich warunków nauki na zdrowie dzieci i młodzieży, postulaty poprawy stanu sanitarno-higienicznego szkół, pod koniec XIX w. zmobilizowały władze galicyjskie do podejmowania działań na polu higieny szkolnej. Ministerstwo Wyznań i Oświecenia oraz Rada Szkolna Krajowa realizowały postulaty higieniczne poprzez opracowywanie różnych aktów prawnych. Wydawano więc liczne rozporządzenia, reskrypty, instrukcje dotyczące budowy gmachów szkolnych, ich urządzania, oświetlania, ogrzewania, wentylacji, odpowiedniego rozkładu zajęć lekcyjnych, nauki gimnastyki itp. Wszystkie akty prawne miały przyczynić się do poprawy istniejącego stanu, w myśl zasady „szkoła ma nie szkodzić zdrowiu uczniów"24. Prasa starała się na bieżąco informować społeczeństwo o działaniach władz, stąd na swoich łamach drukowała wydawane akty prawne ${ }^{25}$.

$\mathrm{W}$ wielu galicyjskich czasopismach zamieszczano sprawozdania $\mathrm{z}$ wystaw, kongresów i zjazdów higienicznych, podczas których poruszano kwestie higieny szkolnej. Sporadycznie poświęcano im oddzielne artykuły, zwykle były to informacje w postaci wiadomości bieżących. Najwięcej tekstów z tego zakresu publikowało „Muzeum”. Przykładowo w 1905 r. zamieściło na swoich łamach notatkę z londyńskiej Konferencji poświęconej higienie szkolnej, w 1910 r. sprawozdanie z Międzynarodowego Kongresu Higieny Szkolnej w Paryżu oraz z XI Zjazdu Lekarzy i Przyrodników Polskich w Krakowie, a w 1914 r. szczegółowe sprawozdanie z I Zjazdu Higienistów Polskich we Lwowie ${ }^{26}$. Teksty

średnich, „Muzeum” 1891, R. VII, s. 304; S. Bądzyński, W sprawie czuwania nad zdrowiem młodzieży szkolnej, „Muzeum” 1901, R. XVII, s. 657; S. Kopczyński, Stanowisko i zadania lekarza szkolnego, „Przegląd Pedagogiczny 1900, nr 7, s. 74, nr 8, s. 87; W. Serbeński, O naglacej potrzebie zorganizowania stużby zdrowia w szkołach publicznych, „Przegląd Higieniczny” 1903, R. II, s. 151-157.

${ }^{24}$ B. Mańkowski, W sprawie higienicznych warunków nauki szkolnej, „Muzeum” 1889, R. XIII, s. $587-597$.

${ }^{25}$ Okólnik Rady Szkolnej Galicyjskiej wydany z powodu panujacych w ostatnich czasach chorób zaraźliwych, „Przegląd Lekarski” 1870, nr 9, s. 71; B. Lutostański, Rozporzqdzenie ministerialne w sprawie higienicznej reformy szkót publicznych, „Przegląd Lekarski” 1871, t. 10, nr 19, s. 145; Dr J. S., Rozporzqdzenie c.k. Ministra Oświaty, wprowadzajqce systematycznq naukę higieny szkolnej $w$ szczególności w szereg przedmiotów objętych planem nauk $w$ seminarium nauczycielskim męskim i żeńskim, „Przegląd Lekarski” 1891, nr 8, s. 114; M. Baranowski, Przepisy szkolne dotyczqce nauki szkolnej, "Szkoła” 1888, nr 14, s. 113; Rozporzqdzenie ministerialne w sprawie fizycznego hartowania młodzieży szkolnej, „Przewodnik Higieniczny” 1890, nr 11, s. 296; Higiena szkolna - rozporzadzenie ministerialne o niej, „Muzeum” 1905, R. XXI, s. 772.

${ }^{26}$ Konferencja poświęcona higienie szkolnej w Londynie, „Muzeum” 1905, R. XXI, s. 424; A. Szycówna, Międzynarodowy Kongres Higieny Szkolnej w Paryżu, „Muzeum” 1910, t. 2, s. 396; Udziat Polaków w III Międzynarodowym Kongresie Higieny szkolnej w Paryżu, „Muzeum” 1910, t. 1, s. 221; XI Zjazd Lekarzy i Przyrodników Polskich, „Muzeum”1910, t. 1, s. 320; I Zjazd 
o podobnej tematyce znajdujemy również w „Szkole”, np. w 1887 r. opublikowano artykuł M. Baranowskiego Kwestja wprowadzenia nauki higieny w szkotach przedmiotem obrad na VI Międzynarodowym Kongresie Higienicznym i Demograficznym w Wiedniu w roku $1887^{27}$. Podczas wymienionych Zjazdów i Kongresów poddawano pod dyskusję koncepcje innowacji higienicznych w szkołach. Tworzono projekty budynków i urządzeń szkolnych spełniających normy higieniczne, analizowano programy nauczania pod kątem wymagań higieny, urządzano wystawy higieniczne.

$\mathrm{Na}$ łamach czasopism pojawiały się również recenzje nowości wydawniczych o tematyce higienicznej, przeznaczonych dla dzieci, młodzieży, rodziców i nauczycieli. Przykładowo w 1892 r. „Przewodnik Higieniczny” zamieścił recenzję dwóch interesujących książek: O pielęgnowaniu zdrowia dla użytku ludu wiejskiego autorstwa Józefa Barzyckiego (Kraków 1892) oraz O pielęgnowaniu i żywieniu dzieci w pierwszym roku życia Leona Jakubowskiego (Kraków 1892). Z kolei czasopismo „Muzeum” w 1908 r. opublikowało recenzję Elementarza higienicznego dla dzieci szkolnych Bronisława Kaczorowskiego (Lwów 1908) i Higieny - podręcznika dla uczniów szkót średnich i samouków Alfreda Winogrodzkiego (Sambor 1908).

Większość czasopism publikowała na swoich łamach pogadanki higieniczne dla dzieci, młodzieży i dorosłych. W prasie pedagogicznej były to najczęściej teksty przekazujące podstawową wiedzę higieniczną. Prezentowano w nich m.in. zasady zdrowego trybu życia, podkreślano znaczenie dla zdrowia higieny osobistej, racjonalnego odżywiania, odpowiedniego ubioru. Wiele miejsca poświęcano również zasadom pielęgnowania i wychowywania dzieci. Taką tematykę poruszały przykładowo artykuły zamieszczane na łamach „Rodziny i Szkoły”28. Cykl wykładów z zakresu higieny dla dzieci, rodziców i nauczycieli opublikowano również w „Muzeum” w $1911 \mathrm{r}^{29} \mathrm{~W}$ ramach pogadanek higienicznych, na łamach czasopism lekarskich i higienicznych omawiano choroby zakaźne i szkolne, ich przyczyny, objawy, metody zapobiegania i leczenia. Na szczególną uwagę zasługują tutaj „Przewodnik Higieniczny” i „Przegląd

Higienistów Polskich we Lwowie, „Muzeum” 1914, t. 2, s. 410; Z programu obrad I Zjazdu Higienistów Polskich we Lwowie, „Muzeum” 1914, t. 2, s. 575.

${ }^{27}$ M. Baranowski, Kwestia wprowadzenia nauki higieny $w$ szkołach przedmiotem obrad na VI Międzynarodowym Kongresie Higienicznym i Demograficznym w Wiedniu w roku 1887, „Szkoła" 1887, nr 38, s. 297.

${ }^{28}$ G. K., Hartowanie, „Rodzina i Szkoła” 1898, nr 9, s. 193; Ile snu potrzebuje młodzież, „Rodzina i Szkoła” 1903, nr 4, s. 13; Higieniczny podziat doby, „Rodzina i Szkoła” 1909, dodatek: Wiedza i Praca, nr 13, 14, 15, 16, s. 109; L. Magierski, Ubranie jako czynnik wychowawczy, „Rodzina i Szkoła” 1909, nr 7/8, s. 97; T. Rafiński, Nieco o ubiorze zimowym, „Rodzina i Szkoła” 1910, nr 3/4, s. 58; B. Antoni, Pielęgnowanie włosów, „Rodzina i Szkoła” 1910, nr 9/10, s. 150; E. Madeyski, Pielegnowanie wzroku, „Rodzina i Szkoła” 1910, nr 17, s. 536.

${ }^{29}$ C. Z., Wyktady higieny dla dzieci i nauczycieli ludowych i rodziców, „Muzeum” 1911, t. 1, s. 111; Wyktady higieny dla matek, „Muzeum” 1911, t. 2, s. 556. 
Higieniczny”, gdzie liczba zamieszczanych artykułów jest największa ${ }^{30}$. W „Przewodniku Higienicznym” istniała stała rubryka „O chorobach zakaźnych”, w której charakteryzowano szczegółowo najczęściej występujące wśród dzieci choroby zakaźne: cholerę, krztusiec, ospę, odrę, błonicę, szkarlatynę, gruźlicę itp., oraz udzielano wskazówek co do postępowania rodziców i nauczycieli w przypadku zachorowań.

Celem wszystkich, tak licznie zamieszczanych w prasie galicyjskiej artykułów z zakresu higieny szkolnej było zwrócenie uwagi społeczeństwa i władz na warunki sanitarno-higieniczne szkół oraz rozbudzenie w społeczeństwie świadomości o potrzebie reform w zakresie higieny. Jak pisał H. Jordan „ważniejszym jest rozbudzenie w ludziach wiedzy higienicznej, niż tworzenie ustaw sanitarnych"31.

Objętość zamieszczanych publikacji w prasie periodycznej była dość obszerna. Choć dominowały teksty dwu- trzystronicowe, to zdarzały się całe cykle wykładów drukowanych w kilku kolejnych numerach. Zamieszczano również krótkie wiadomości bieżące $\mathrm{w}$ formie doniesień i informacji.

Część spośród opublikowanych materiałów ukazywała się w czasopismach jako noty redakcyjne. Sporą grupę stanowily publikacje sygnowane jedynie inicjałami. U schyłku autonomii było ich jednak mniej, a większość stanowiły publikacje podpisywane imieniem i nazwiskiem. Autorami artykułów z zakresu higieny szkolnej byli przede wszystkim współpracownicy czasopism, członkowie towarzystw lekarskich i higienicznych, naukowcy, lekarze, higieniści, propagatorzy wychowania fizycznego, psychologowie, nauczyciele szkół ludowych i średnich. Do wybitnych publicystów piszących o higienie szkolnej należał Henryk Jordan (1842-1907) - lekarz, pedagog, pionier nowoczesnego wychowania pozaszkolnego, twórca parku dr Henryka Jordana w Krakowie ${ }^{32}$. W licznych artykułach udowadniał społeczeństwu wpływ ruchu i higienicznego trybu życia na zdrowie. Zachęcał młodzież do uprawiania sportów, odpoczynku na świeżym powietrzu, dbania o higienę osobistą. Postulował reformę higieniczną szkół. Wśród publicystów lekarzy, zajmujących się problematyką higieniczną szczególną rolę odegrał Tadeusz Żuliński (1839-1885) - lekarz

${ }^{30}$ Choroby w Galicji, „Przewodnik Higieniczny” 1889, nr 7, s. 1; E. Piasecki, W sprawie hygieny ptciowej młodzieży szkolnej. Garść uwag wygłoszonych w pogadankach rodzicielskich w gimnazjum III i IV we Lwowie, „Przegląd Higieniczny” 1906, nr 5, s. 113-121; R. Palmstein, Rzecz o pielęgnowaniu zdrowia i ćwiczeniu ciała w naszych czasach, „Przewodnik Gimnastyczny «Sokół»" 1885, nr 10, s. 79, nr 11, s. 87, nr 12, s. 94; J. Kramsztyk, Znaczenie higieny w wieku dziecięcym. Główne przyczyny chorób wieku dziecięcego. Śmiertelność i chorobowość dzieci, „Przegląd Pedagogiczny” 1900, nr 22, s. 254.

${ }^{31}$ H. Jordan, O wptywie higieny na zdrowie, życie i pracę człowieka, „Przegląd Higieniczny” 1889 , nr 8, s. 13. ków 1958.

${ }^{32}$ H. Smarzyński, H. Jordan pionier nowoczesnego wychowania fizycznego w Polsce, Kra- 
szkolny, higienista, wykładowca higieny szkolnej, twórca i redaktor „Przewodnika Gimnastycznego" ${ }^{\text {"3 }}$. Na łamach czasopism upowszechniał zasady higieniczne, dzielił się informacjami $\mathrm{z}$ międzynarodowych zjazdów lekarskich i higienicznych, w których brał czynny udział. Na uwagę zasługuje również Bronisław Kaczorowski (1857-1932) - lekarz szkolny, redaktor „Przeglądu Higienicznego" ${ }^{\prime 3}$. W czasopismach publikował liczne sprawozdania i prace badawcze dotyczące zdrowia i rozwoju dzieci szkolnych, oparte na materiale empirycznym. Wiele artykułów z zakresu higieny szkolnej publikował też Mieczysław Baranowski (1851-1898) - redaktor „Szkoły” i współredaktor „Rodziny i Szkoły”35. Treść jego artykułów dotyczyła najczęściej sytuacji sanitarno-higienicznej galicyjskich szkół. Interesujace artykuły publikował również Odo Bujwid (1857-1942) - bakteriolog, kierownik katedry higieny na Uniwersytecie Jagiellońskim ${ }^{36}$. Jako autora licznych artykułów o treści higienicznej należy również wymienić Edwarda Madeyskiego (1832-1906) - wybitnego teoretyka wychowania fizycznego, autora podręcznika do higieny Dietetyka dzieci oparta na wskazówkach przyrody (Lwów 1869) oraz pierwszego polskiego przewodnika metodycznego dla nauczycieli gimnastyki Gimnastyka w szkołach ludowych. Instrukcja dla nauczycieli (Lwów 1879) ${ }^{37}$. Na łamach „Szkoły” oraz „Rodziny i Szkoły” interesujące artykuły o stanie higienicznym szkół galicyjskich zamieszczał również Bolesław Adam Baranowski (1844-1916) - pedagog, krajowy inspektor szkolny, w latach 1882-1884 redaktor „Szkoły”38.

Wśród nauczycieli publikujących artykuły o higienie szkolnej spotykamy nazwiska: Edmunda Cenara (1856-1913) - nauczyciela wychowania fizycznego w szkole ludowej we Lwowie oraz w IV Gimnazjum w tym mieście, a także współorganizatora Towarzystwa Zabaw Ruchowych; Teofila Gerstmana (18431907) - dyrektora i nauczyciela Szkoły Realnej, działacza społecznego, współtwórcę kolonii wakacyjnych w Galicji; Eugeniusza Piaseckiego (1872-1947) nauczyciela gimnastyki w gimnazjach krakowskich i lwowskich, twórcę polskiej teorii wychowania fizycznego, współzałożyciela Towarzystwa Zabaw Ruchowych; Józefa Żulińskiego (1841-1908) - wybitnego pedagoga, nauczyciela z lwowskiego Państwowego Seminarium Żeńskiego, inicjatora kolonii i korpu-

${ }^{33}$ E. Dolata, T. Żuliński - biogram, [w:] Galicja i jej dziedzictwo, red. A. Meissner, t. 16, Opieka nad dzieckiem w Galicji, Rzeszów 2002, s. 118-121.

${ }^{34}$ M. Demel, $Z$ dziejów promocji zdrowia w Polsce, Kraków 2000, s. 83.

${ }^{35}$ K. Bruchnalski, Baranowski Mieczystaw Tytus, [w:] Polski Stownik Biograficzny, t. 1, Kraków 1935, s. 282.

${ }^{36}$ M. Demel, dz. cyt.

${ }^{37}$ K. Toporowicz, Madeyski Edward, [w:] Polski Słownik Biograficzny, t. 19, WrocławWarszawa-Kraków-Gdańsk, s. 120.

${ }^{38}$ A. Meissner, Bolesław Adam Baranowski - przedstawiciel galicyjskiej pedagogiki urzędowej, [w:] Galicja i jej dziedzictwo, red. Cz. Majorek, J. Potoczny, t. 9, Biografie pedagogiczne, Rzeszów 1997, s. 81-92. 
sów wakacyjnych dla dzieci w Galicji; Antoniego Durskiego (1854-1908) - jednego $\mathrm{z}$ twórców systemu sokolego, propagatora ćwiczeń na świeżym powietrzu ${ }^{39}$.

Publikacje o tematyce higienicznej przygotowywali głównie mieszkańcy Galicji, ale nadsyłali je także mieszkańcy innych zaborów, wśród nich warto wymienić nazwiska największych polskich higienistów z Warszawy: Józefa Polaka, Stanisława Kopczyńskiego, Leona Wernica. Zdarzały się również artykuły autorstwa zagranicznych korespondentów. Przykładowo w czasopiśmie „Szkoła” w roku 1904 ukazał się cykl publikacji hr. Czesława Pruszyńskiego, pochodzącego z Wołynia i nadsyłającego swoje relacje ze zwiedzanych szkół angielskich $^{40}$.

Początkowo autorami zdecydowanej większości publikacji byli mężczyźni. Stopniowo, wraz z postępującym procesem emancypacji oraz zdobywaniem wykształcenia, powstawało coraz więcej publikacji, których autorkami były kobiety. Sygnowały one zrazu swe teksty jedynie kryptonimami, natomiast pod koniec doby autonomicznej podpisywały je pełnymi imionami i nazwiskami. Wybitną autorką artykułów w pismach pedagogicznych była Aniela Szycówna (1869-1921). Spod jej pióra wychodziły opracowania i thumaczenia obcych dzieł pedagogicznych oraz relacje o stanie oświaty ${ }^{41}$. Liczne artykuły publikowały również Izabela Moszczeńska (1864-1941) - działaczka społeczno-oświatowa oraz Matylda Biehler (1881-1953) - lekarka, nauczycielka higieny na pensjach żeńskich, autorka podręcznika do higieny ${ }^{42}$.

Nie ulega wątpliwości, że na przełomie XIX i XX w. prasa galicyjska była niezmiernie ważnym forum wymiany poglądów w dziedzinie szeroko rozumianych problemów społecznych i edukacyjnych, a wśród nich zagadnień zdrowia i higieny. Ilość artykułów odnoszących się do zagadnień higieny szkolnej potwierdza fakt, iż czasopisma mocno zaangażowały się w działania mające na celu poprawę warunków sanitarno-higienicznych i zdrowotnych w szkołach galicyjskich. W oparciu o liczne publikacje starały się upowszechnić podstawową wiedzę higieniczną w społeczeństwie i zapoznać ludność z podstawowymi

${ }^{39}$ E. Piasecki, Cenar Edmund, [w:] Polski Stownik Biograficzny, t. 3, Kraków 1937, s. 227; E. Dolata, Piasecki Eugeniusz, [w:] Encyklopedia Pedagogiki XXI wieku, t. 4, Warszawa 2005, s. 369-373; E. Dolata, J. Żuliński i jego wktad $w$ organizację kolonii dziecięcych $w$ Galicji, Rocznik Komisji Nauk Pedagogicznych, t. 54, Kraków 2001, s. 17-29; M. Wolańczyk, Durski Antoni Maciej, [w:] Polski Stownik Biograficzny, t. 6, Kraków 1948, s. 11.

${ }^{40}$ C. Pruszyński, Bedelas, Nowa szkoła w Anglii, „Szkoła” 1904, s. 150-151, 157-159, 182183, 196-197, 205-206, 212, 213.

${ }^{41}$ A. Szycówna, Nauka szkolna a zdrowotność dzieci - w świetle nowych badań, Warszawa 1909, s. 237.

42 I. Moszczeńska, Choroba na pensji, „Przegląd Pedagogiczny” 1900, nr 22, s. 257; Zasady wychowania, „Muzeum” 1908, t. 1, s. 14-18; Nauczyciel wobec dzisiejszych wymagań higieny, „Przegląd Pedagogiczny” 1902, nr 5, s. 53, Nadużycia higieny, „Przegląd Pedagogiczny” 1902, nr 19, s. 227. 
zasadami zdrowego stylu życia. Poza tym usiłowały zainteresować władze krajowe losem dzieci i młodzieży, żyjących i uczących się w skandalicznych warunkach, a poprzez publikowane petycje i apele próbowały zmobilizować je do podejmowania działań naprawczych. Można uznać, iż dzięki tak dużemu zainteresowaniu się prasy galicyjskiej problemami higieny szkolnej zdołano obudzić społeczną inicjatywę, w efekcie której, pod koniec XIX w. stopniowo zaczęła zmieniać się galicyjska rzeczywistość szkolna. Władze krajowe i szkolne wydały szereg ustaw, rozporządzeń i instrukcji, zawierających normy higieniczne, którym miały odpowiadać szkoły. Zakres ich realizacji był oczywiście ograniczony z przyczyn finansowych, mimo to powoli poprawiały się warunki lokalowe i baza dydaktyczna szkół. Powstawać zaczęły nowe budynki, odpowiadające przepisom higienicznym, wiele szkół wyremontowano, zreformowano programy nauczania, ustanowiono instytucję lekarzy szkolnych. Wiedza z zakresu higieny została wykorzystana w procesie wychowania dzieci i młodzieży, znacznie go wzbogacając i czyniąc bardziej skutecznym i efektywnym. 